\title{
Comparative Characterization of Foxtail Millet, Physico-Chemical Approach for its Suitability to Celiacs
}

\section{Ajay Singh ${ }^{1 *}$ and Bahadur S Hathan ${ }^{1}$}

${ }^{1}$ Department of Food Engineering and Technology, Sant Longowal Institute of Engineering and Technology, Sangrur (Pb), India

\begin{abstract}
This investigation Focused on comparative physico-chemical characterization of Foxtail millet in the form of pearling and germination and the changes evaluated with raw grains and staple cereals as well. Proximate outcomes showed no marked differences after treatments. These pre-treatments resulted in $58 \%$ and $83 \%$ reduction in total polyphenols, $43 \%$ and $53 \%$ reduction in phytic acid for germinated and pearled flour respectively. Calcium, Iron and Zinc content lies at $24.1 \mathrm{mg} / \mathrm{g}, 4.2227$ $\mathrm{mg} / \mathrm{g}$ and $1.0499 \mathrm{mg} / \mathrm{g}$ respectively in germinated grains, which decreased to $18.88 \mathrm{mg} / \mathrm{g}, 2.5504 \mathrm{mg} / \mathrm{g}$ and $0.4635 \mathrm{mg} / \mathrm{g}$ after pearling. Observations for comparable antioxidant capacity of bran depict its nutraceutical characteristics. Lowering of peak viscosity value from $46.20 \mathrm{cP}$ for pearled to $4.17 \mathrm{cP}$ for germinated proves its suitability for bakery consideration. Results from the above investigation can be a basis to consume it as staple diet.
\end{abstract}

Keywords: Foxtail millet; Germination; Pearling; Phenolic content; Phytic acid

\section{Introduction}

Whole world consume cereals in various forms in their staple diet, ignoring the value and nutritional richness of millets. Cereals, no doubt are good but deficient in certain essential nutrients [1]. These cereals by certain group of peoples can't be consumed due to their ill effects. Wheat and its interrelated species i.e. rye (secalins), barley (hordeins) and oat (avenins) etc. are not consumed by gluten allergic population [2]. Celiac patients are sensitive towards gluten protein present in wheat and its cross bread varieties. These patients strict to a lifelong gluten free diet. The number of celiacs patients in north Indian community is 1 in 96. It is more common than is recognized in India [3]. Prevalence of celiac disease is absent in Japan where rice is the staple diet [4].

The minor millets are (as opposed to other millets like pearl millet and sorghum) also described as gluten free nutritious grain and have received far less attention than other crops in regard of crop improvement, cultivation practices and utilization due to presence of some antinutrients [5]. These anti-nutrients reside in the form of tannin that hinders protein absorption, oxalates that restrict calcium absorption and the major phytic acid that restricts the minerals bioavailability, eradicated by applying minimal preprocessing treatments. The phytic acid is the primary source of storage phosphorous in plant seeds, but this form of phosphorous is unavailable to monogastric animals i.e. human beings because of lack of intestinal digestive enzyme phytase required for dephosphorylation of phytic acid [6]. Phytate is also known by the name myoinositol $(1,2,3,4,5,6)$ hexakisphosphoric acid. This unique structure of phytate possesses the chelating characteristics for divalent cations i.e. $\mathrm{Ca}^{2+}, \mathrm{Zn}^{2+}, \mathrm{Mg}^{2+}, \mathrm{Mn}^{2+}$ and $\mathrm{Fe}^{2+}$ thus lowers their bioavailability by making insoluble salts [7]. So as to make these divalent cations bioavailable, pretreatments in the form of germination activates the phytase enzyme which feeds on phytate [8]. Soaking leaches the phytate (water soluble) in water, pearling or debranning or decortications removes outer layers of seed (maximum antinutrients prone area) and fermentation with lactic cultures results in lowering of $\mathrm{pH}$ as production of lactic or acetic acid, making conditions suitable for phytase [9-13]. In addition, Phytate forms a strong complex with few of the proteins of human concern and resists their proteolysis [14]. Phytate and protein interaction is totally $\mathrm{pH}$ and calcium dependent because divalent calcium is necessary for the activity of trypsin, protease and $\alpha$-amylase [15].

Keeping in view the above aspects, experiments were conducted to study the various physico-chemical properties of foxtail millet (Setaria italica) for its use as basic ingredients in designing gluten free diet and antinutrients minimization as well, by spreading awareness about minimal pre-processing treatments.

\section{Materials and Methods}

Grains were procured from local market of Guntur (Andhra Pradesh). To study the effect of various treatments on physicochemical properties of foxtail millet, these were germinated and pearled. The treated as well as raw grains were analysed for proximate value, antioxidant activity, phytic acid test, pasting property, colour value evaluation, mineral estimation and total phenols.

\section{Sample preparation}

Millet grains were used after thorough cleaning and removal of soil and extraneous matter. Grains were directly ground using homemade Natraj atta chakki to obtain a fine powder passing through a mesh 16 sieve. Another portion of whole millet grains was dehulled using pearler (Vivek mandua agricultural implements). The hull was separated by air winnowing. A portion of dehulled grains and bran were ground separately to obtain fine powder and sieved through 16 mesh size. One more portion of whole millet seeds was allowed to germinate at $25^{\circ} \mathrm{C}$ for 48 to $72 \mathrm{~h}$ till the achievements of 3 to $4 \mathrm{~mm}$ long rootlets. Separation of rootlets from grains was done by hand rubbing after tray drying for 18 to $24 \mathrm{~h}$ at $55^{\circ} \mathrm{C}$ and both the fractions were ground and sieved separately in a similar manner.

*Corresonding author: Ajay Singh, Department of Food Engineering and Technology, Sant Longowal Institute of Engineering and Technology, Sangrur (Punjab), India, Tel: +91-98963-00039; E-mail: ajay3singh@gmail.com

Received September 06, 2014; Accepted October 07, 2014; Published October 14,2014

Citation: Singh A, Hathan BS (2014) Comparative Characterization of Foxtail Millet Physico-Chemical Approach for its Suitability to Celiacs. J Food Process Technol 5 382. doi:10.4172/2157-7110.1000382

Copyright: ( 2014 Singh A, et al. This is an open-access article distributed unde the terms of the Creative Commons Attribution License, which permits unrestricted use, distribution, and reproduction in any medium, provided the original author and source are credited. 


\section{Pre-treatment}

Seeds were germinated after soaking for $24 \mathrm{~h}$ in aerated fresh water with $0.1 \%$ formaldehyde solution to avoid mould growth followed by washing with running potable water followed by Spreading on muslin cloth in $1 \mathrm{~mm}$ thick layer and incubation was carried out at $25^{\circ} \mathrm{C}$ till achievement of rootlets [9]. After scrapping from muslin cloth, seeds were dried in tray drier at $55^{\circ} \mathrm{C}$ for 12 to $24 \mathrm{~h}$ to a moisture content of 12 to $14 \%$. Dried seeds made free from rootlets.

\section{Proximate study}

By applying AOAC methods using Microkjehldal method for crude protein estimation followed by digestion of samples, distillation of digest with saturated boric acid and $50 \% \mathrm{NaOH}$ and finally titration of it with $0.01 \mathrm{~N}$ acid (AOAC, 2000), muffle furnace (Modern Industrial Corporation, Bombay) for total ash (AOAC, 2000), Soxplus (Pelican equipments) for crude fat (AOAC, 1995), Fibraplus (Pelican equipments) for crude fibre (AOAC, 2000), and hot air oven for moisture determination (AOAC, 2000). The carbohydrate component concentration was calculated by difference as.

\section{Phytate content}

Phytate was estimated through Megazyme phytic acid kit. After sample extraction from $1 \mathrm{~g}$ of flour using methanol, it was subjected to colour development using kit content (buffers, enzyme suspensions, ammonium molybdate and Vit. C). Reaction was stopped using Trichloro acetic acid solution (50\% w/v), centrifuge it at $13000 \mathrm{rpm}$, supernatant was observed spectrophotometrically at $655 \mathrm{~nm}$ against water as blank.

\section{Colorimetric study}

Foxtail millet grains and flour were measured for color difference using Colorflex colorimeter (Hunter Associated Laboratory, Inc., VA, USA) and described in terms of $\mathrm{L}^{*}$ (Lightness), ranging from zero (black) to 100 (white), $\mathrm{a}^{*}$ (Redness), ranging from +60 to -60 (green) and $b^{*}$ (yellowness), ranging from +60 (yellow) to -60 (blue) values using dual beam Xenon flash lamp as light source.

\section{Mineral estimation}

Minerals were elucidated by employing dry digestion method using AA-7000 atomic absorption spectrophotometer (Shimadzu, Japan) using air-acetylene flame against range of standards and blank. Ash was prepared by taking $1 \mathrm{gm}$ of milk samples in silica crucibles followed by heating on hot plate to complete charring. The charred samples were incinerated in a muffle furnace at $550^{\circ} \mathrm{C}$ for $3-4 \mathrm{~h}$ till white ash was obtained.

The dishes with samples were cooled in a dessicator to room temperature and $1 \mathrm{ml}$ concentrated nitric acid was added to dissolve the ash, contents were then transferred to volumetric flask and volume was made up to dilution so that the concentration falls within the range of standard solutions concentration (Figure 1).

\section{Total phenol estimation}

Folin Ciocaltau reagent was utilized for phenolic estimation in raw, germinated, pearled, hull and rootlets flour by extracting them in acidified methanol solution for a minimum of $2 \mathrm{~h}$. After using $10 \%$ FC reagent, $15 \% \mathrm{Na}_{2} \mathrm{CO}_{3}$ and incubation in dark OD were taken at $734 \mathrm{~nm}$ against water as blank.

\section{Antioxidant study}

Antioxidant capacity was established by evaluating it with Trolox standard curve using DPPH (2, 2-diphenyl-1-pikrahydrazyl) solution [13]. The sample were analysed spectrophotometrically (Backman coulter) at $517 \mathrm{~nm}$ with a reference to distilled water as blank only after employing a controlled procedure of mixing of $0.1 \mathrm{mM} \mathrm{DPPH}$ solution with test sample and incubating it for about 30 minutes.

\section{Pasting behaviour}

Pasting properties of raw, germinated and pearled flour were determined using a Viscoamylograph Rapid Visco Analyser (RVA-4, Newport Scientific Pvt. Ltd., Warriewood, Australia) Model 3-D by Newport Scientific Method 1, Version 5, December 1997 with profile STD 1.

\section{Statistical analysis}

Statistical study in triplicates were analysed and compiled by statistical means using ANOVA (Analysis of Variation) through SPSS 8.0 computer software and depicts in significant form $(\mathrm{p}>0.05)$.

\section{Results and Discussion}

The outcomes were analysed on the basis of different pre-treatment effects on grain in a correlation with untreated grains. Germination and pearling have positive influence in lowering of antinutrients and increase in nutritional richness.

\section{Proximate estimation}

Present work under this heading shows its superiority in terms of protein, fat, mineral and crude fibre comparable to staple cereals where lower value of carbohydrate for FM $\left(71.14 \pm 3.5^{\mathrm{a}}\right)$ seems to be highly significant $(\mathrm{p}<0.05)$ in comparison to that of wheat $\left(74.98 \pm 6.89^{\mathrm{b}}\right)$ and rice $\left(81.21 \pm 7.80^{\mathrm{c}}\right)$ (Table 1$)$. Ash and moisture content revealed nonsignificant differences for the same grains $(\mathrm{p}>0.05)$. On the other hand FM for protein $\left(12.57 \pm 1.22^{\mathrm{a}}\right)$, fat $\left(3.22 \pm 0.41^{\mathrm{a}}\right)$ and crude fibre $(10.21$ $\left.\pm 1.67^{\mathrm{a}}\right)$ shows significant difference $(\mathrm{p}<0.05)$ in comparison with wheat and rice.

\section{Quantitative estimation for phytic acid}

When the Pre-treated seeds of foxtail millet in the form of germination and debranning, rootlets (germinated sprouts) and bran (pearled matter) ground to become flour and subjected to phytic acid estimation through megazyme kit. Germination resulted $(\mathrm{g} / 100 \mathrm{~g})$ in the significant reduction of phytic acid content from $4.80 \pm 0.89^{\mathrm{a}}$ (raw

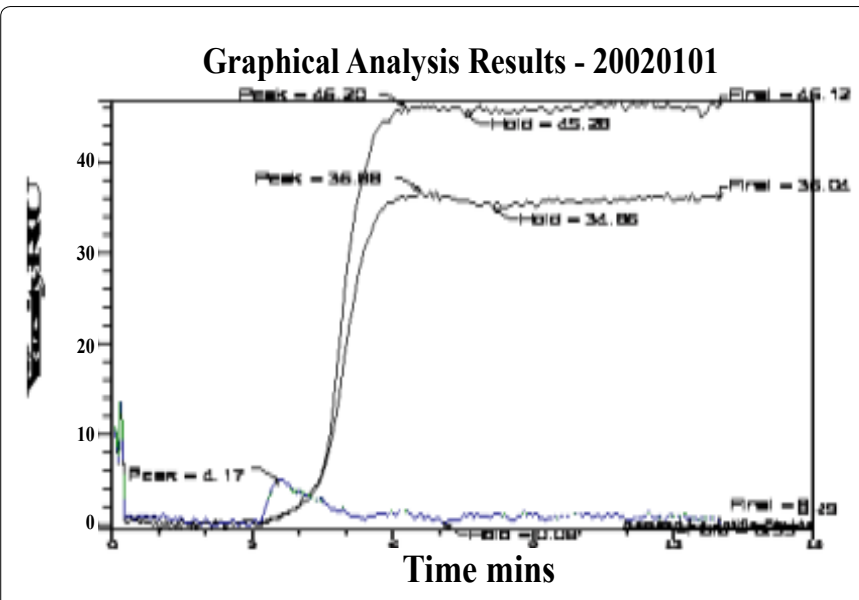

Figure 1: Peak Viscosity study through Rapid Visco Analyser showing peak viscosity values 
seed) to $2.56 \pm 0.05^{\mathrm{b}}$ (Germinated) (Table 2). This is usually due to the action of phytase enzyme that feeds on phytate (phytic acid). As phytate is water soluble so prior soaking in aerated water overnight also has significant role in leaching of phytate into water [16]. Usually the pearling of raw samples results in reduction of phytic acid from $4.80 \pm 0.89^{\mathrm{a}}$ (raw) to $2.18 \pm 0.056^{\mathrm{b}}$ (Pearled). This higher reduction of antinutrients in pearling attributed to the reason that most of the phytate and tannins reside in the bran layer $3.11 \pm 0.09^{c}$ which on proper pearling get removed in the form of bran. Germinated rootlet shows comparable value of antinutrients $2.63 \pm 0.05^{\mathrm{b}}$ that may be because of their leaching from endosperm and bran of seed to the germinal pore side. So, on the basis of these results, effectiveness of treatment decreases as we move from germination \& pearling both for the same seed to pearling only and lastly to germination only.

Germination make it free from phytate by activating its internal enzymes i.e. phytases. As phytate is heat stable component, however the intrinsic plant phytases are thermolabile. Therefore sometimes heat stable phytases from external origin has been recommended for phytate degradation.

\section{Effect of pre-treatments on colour value}

Rise in the $L^{*}$ value shows availability of more available sites for light absorption when proceeded from germinated to pearled sample. While germinated rootlets flour showed less value which further decreases for hull flour.

Same observations were appeared when analyzed for seeds in the same pattern from raw to treated one. Value for $\mathrm{a}^{*}$ in the colorflex colorimeter showed decreasing pattern which enormously doubles for hull and rootlets flour, while decreases slightly for seeds in the same range (Table 2). At last value of $b^{*}$ gets diminished slightly after the treatments, proving that removal of outer bran layer lowers the $b^{*}$ value for seeds as well as flour that was not obeyed by germinated rootlets of seeds and flour both.

\section{Mineral content in germinated and pearled flour samples}

Calcium, Iron and Zinc values reside in $24.1 \mathrm{mg} / \mathrm{kg}$, $4.2227 \mathrm{mg} / \mathrm{kg}$ and $10.0499 \mathrm{mg} / \mathrm{kg}$ respectively in germinated grains while for pearling results in shifting of these values as $18.88 \mathrm{mg} / \mathrm{kg}, 2.5504 \mathrm{mg} / \mathrm{kg}$ and $5.6635 \mathrm{mg} / \mathrm{kg}$. These observations prove it the most efficient grain as these minerals are necessary for teeth, bone formation and various proenzymatic activities in the body.

\section{Total phenol estimation}

Phenols also recognized as antioxidants, have been known for their protective function against oxidative damage, but sometimes protein, minerals and carbohydrate digestibility gets impaired on its interaction with non protein components such as polyphenols (tannins), dietary fibre and phytate [17] (Table 2). Debranning and germination resulted $(\mathrm{mg} / \mathrm{g})$ in decrease phenol concentration from raw seeds $19.58 \pm 1.78$

\begin{tabular}{|c|c|c|c|c|c|}
\hline Parameters & $\begin{array}{c}\text { Raw FM } \\
\text { (mg/g) }\end{array}$ & $\begin{array}{c}\text { GFM } \\
\text { (mg/g) }\end{array}$ & $\begin{array}{c}\text { PFM } \\
(\mathbf{m g} / \mathbf{g})\end{array}$ & $\begin{array}{c}\text { Wheat } \\
\mathbf{( m g / g )}\end{array}$ & $\begin{array}{c}\text { Rice } \\
(\mathbf{m g} / \mathbf{g})\end{array}$ \\
\hline Protein & $12.57 \pm 1.22^{\mathrm{a}}$ & $10.82 \pm 1.34^{\mathrm{b}}$ & $12.02 \pm 1.34^{\mathrm{a}}$ & $11.8 \pm 0.57^{\mathrm{c}}$ & $6.8 \pm 0.87^{\mathrm{d}}$ \\
\hline Fat & $3.22 \pm 0.41^{\mathrm{a}}$ & $2.75 \pm 0.59^{\mathrm{b}}$ & $3.55 \pm 0.59^{\mathrm{a}}$ & $1.5 \pm 0.045^{\mathrm{c}}$ & $0.6 \pm 0.21^{\mathrm{d}}$ \\
\hline Minerals & $3.14 \pm 0.36^{\mathrm{a}}$ & $3.05 \pm 0.73^{\mathrm{a}}$ & $3.10 \pm 0.73^{\mathrm{a}}$ & $1.5 \pm 0.08^{\mathrm{b}}$ & $1.5 \pm 0.05^{\mathrm{b}}$ \\
\hline Carbohydrates & $71.14 \pm 3.5^{\mathrm{a}}$ & $71.91 \pm 2.45^{\mathrm{a}}$ & $71.96 \pm 2.45^{\mathrm{a}}$ & $74.98 \pm 6.89^{\mathrm{b}}$ & $81.21 \pm 7.80^{\mathrm{c}}$ \\
\hline Crude fibre & $10.21 \pm 1.67^{\mathrm{a}}$ & $10.03 \pm 1.45^{\mathrm{a}}$ & $6.93 \pm 1.45^{\mathrm{b}}$ & $1.2 \pm 0.023^{\mathrm{c}}$ & $0.2 \pm 0.01^{\mathrm{d}}$ \\
\hline Moisture & $9.93 \pm 1.89^{\mathrm{a}}$ & $10.07 \pm 0.98^{\mathrm{a}}$ & $9.95 \pm 0.98^{\mathrm{a}}$ & $10.22 \pm 0.90^{\mathrm{a}}$ & $9.89 \pm 1.23^{\mathrm{a}}$ \\
\hline
\end{tabular}

Data are presented as means \pm SEM $(n=3)$. Means with the different superscripts $(a, b, c, d)$ in a row are significantly different $(P<0.05)$ from each other. Statistical comparisons were made between samples using ANOVA single factor. FMFoxtail Millet, GFM- Germinated Foxtail Millet. PFM: Pearl Foxtail millet

Table 1: Proximate result for Foxtail Millet (raw and treated) in comparison with Wheat and Rice

\begin{tabular}{|c|c|c|c|c|c|c|c|c|c|}
\hline \multirow{2}{*}{$\begin{array}{c}\text { Kind of } \\
\text { treatment grains } \\
\text { (Seeds) }\end{array}$} & \multicolumn{3}{|c|}{ Colour } & \multirow{2}{*}{$\begin{array}{l}\text { Phytic acid } \\
\text { (g/100g) }\end{array}$} & \multirow{2}{*}{$\begin{array}{c}\text { Polyphenol } \\
\text { Conent (GAE } \\
\mathrm{mg} / \mathrm{g})\end{array}$} & \multicolumn{3}{|c|}{ Mineral Content $(\mathrm{mg} / \mathbf{1 0 0 g})$} & \multirow{2}{*}{$\begin{array}{c}\text { Antioxidant } \\
\text { activity } \\
\text { (Trolox eq. } \mu / \\
\text { gm) }\end{array}$} \\
\hline & $L^{*}$ & $a^{*}$ & $\mathbf{b}^{*}$ & & & $\mathrm{Fe}$ & $\mathrm{Ca}$ & Zn & \\
\hline RFMS & 38.903 .89 & $7.70 \pm 0.56$ & $22.00 \pm 2.34$ & - & - & & & & - \\
\hline RFM F & $61.38 \pm 5.89$ & $3.91 \pm 0.12$ & $16.20 \pm 1.23$ & $4.80 \pm 0.89$ & $16.404 \pm 1.23$ & $3.47 \pm 0.22$ & $26.44 \pm 4.56$ & $0.55 \pm 0.04$ & $98.05 \pm 5.78$ \\
\hline GFMS & $40.28 \pm 2.69$ & $6.53 \pm 0.05$ & $20.26 \pm 0.98$ & - & - & & & & - \\
\hline GFMF & $65.43 \pm 6.67$ & $2.68 \pm 0.45$ & $12.55 \pm 1.34$ & $2.56 \pm 0.05$ & $11.49 \pm 0.67$ & $4.22 \pm 0.9$ & $24.1 \pm 2.56$ & $1.04 \pm 0.03$ & $97.29 \pm 5.90$ \\
\hline PFMS & $55.94 \pm 2.45$ & $5.05 \pm 0.12$ & $20.07 \pm 2.67$ & - & - & & & & - \\
\hline PFM F & $72.48 \pm 4.56$ & $2.38 \pm 0.40$ & $13.24 \pm 0.09$ & $2.18 \pm 0.056$ & $28.02 \pm 1.67$ & $98.05 \pm 5.78$ & $98.05 \pm 5.78$ & $98.05 \pm 5.78$ & $95.08 \pm 2.56$ \\
\hline Bran(Hull) & $40.11 \pm 1.29$ & $5.95 \pm 0.34$ & $18.56 \pm 0.56$ & - & - & - & - & - & - \\
\hline HF & $45.89 \pm 3.56$ & $5.95 \pm 0.12$ & $19.52 \pm 0.86$ & $3.11 \pm 0.09$ & $7.54 \pm 0.45$ & - & - & - & $97.65 \pm 8.89$ \\
\hline GR & $52.97 \pm 0.98$ & $5.68 \pm 0.56$ & $23.12 \pm 3.56$ & - & - & - & - & - & - \\
\hline GRF & $58.61 \pm 4.56$ & $5.15 \pm 0.45$ & $19.58 \pm 2.45$ & $2.63 \pm 0.05$ & $19.58 \pm 1.78$ & - & - & - & $98.05 \pm 7.09$ \\
\hline
\end{tabular}

Data are presented as means \pm SEM $(n=3)$. Means with the different superscripts $(a, b)$ in a row and in a column $(A, B)$ are significantly different $(P<0.05)$ from each other.

Statistical comparisons were made between samples using ANOVA single factor

RFMS: Raw Foxtail, millet Seeds

RFMF: Raw Foxtail millet Flour

GFMS: Germinated Foxtail millet seeds

GFMF: Germinated

Foxtail millet Flour, PFMS: Pearl

Foxtail millet Seeds

PFMF: Pearl

Foxtail: millet

Flour HF: Hull

Flour, GR: Germinated Rootlets, GRF:

Germinated Rootlets Flour

Data are presented as means \pm SEM $(n=3)$. Means in each column with same superscripts $(a, b, c, d, f, g, h, i))$ were not significantly different $(P>0.05)$ from each other Statistical comparisons were made between samples using ANOVA single factor,

FM GAE

Table 2: Physico-chemical study of different kind of treatment grain 


\begin{tabular}{|l|l|l|l|l|l|}
\hline \multicolumn{7}{|c|}{ Flour } \\
\hline & $\begin{array}{c}\text { Peak } \\
\text { viscosity (cp) }\end{array}$ & $\begin{array}{c}\text { Trough } \\
\text { viscosity (cp) }\end{array}$ & $\begin{array}{c}\text { Breakdown } \\
\text { (cp) }\end{array}$ & $\begin{array}{c}\text { Final } \\
\text { viscosity } \\
\text { (cp) }\end{array}$ & $\begin{array}{c}\text { Setback } \\
\text { (cp) }\end{array}$ \\
\hline Raw & 36.88 & 34.86 & 2.02 & 36.04 & 1.18 \\
\hline Pearled & 46.2 & 45.28 & 0.92 & 46.12 & 0.84 \\
\hline Germinated & 4.17 & 0.33 & 3.83 & 0.83 & 0.5 \\
\hline
\end{tabular}

Table 3: Results for pasting properties for treated and raw samples

to the pearled $11.49 \pm 0.67^{\mathrm{b}}$ due to removal of outer layer of seeds, as phenols are embedded in the pericarp and aleurone layer of seeds. Germination lowers phenolic concentration to $16.404 \pm 1.23^{\mathrm{a}}$ level. This result for reduction in TPC after germination is in consistent with the findings of Abdoulay [18]. Confirmation regarding phenol location in the pericarp layer was evaluated only after applying the same findings for flour. The removed rootlets from germinated seeds were observed to show the maximum level even two fold $\left(28.02 \pm 1.67^{c}\right)$ as a comparison with pearled grains, which may be attributed due to the rupture of ester bonds of phenols by the action of esterase enzymes. Removed hull also shows phenolic concentration to a level of $7.54 \pm 0.45^{\mathrm{d}}$. Present data reveals that germination itself has no such pronounced effect as that of pearling in lowering of phenolic power of millets.

\section{Antioxidant study}

Outcomes in the form of antioxidant power $(\mu \mathrm{g} / \mathrm{g})$ with DPPH show effective inhibition of DPPH radicals. Decrease in the antioxidant capacity of germinated grains $97.29 \pm 5.90^{\mathrm{b}}$ in a comparison with raw grains $98.05 \pm 5.78^{\text {a }}$ could be due to the soaking of seeds. Comparable value for hull $97.65 \pm 8.89^{\mathrm{b}}$ contributes to its potential as nutraceutical for improving health and reducing risk for diseases. High phenolics value of hull account for its high radical scavenging activity. The results for antioxidant capacity are corroborated with the findings of Chandrasekara [19] in the decreasing order from Raw FM Flour > Hull Flour $>$ Germinated FM Flour.

\section{Pasting properties of foxtail millet flour}

The graph obtained by RVA for germinated Foxtail millet flour does not show any clear indication for peak time, holding time and final point. This might be due to consumption of whole starch content by the enzymes.

Soaking of grains prior to germination resulted in imbibitions of water that is necessary for activation of amylases which further on incubation allows those activated enzymes to feed on the starch. Raw seeds have a slightly higher value for pasting properties in a comparison with pre-treated samples (Table 3). RVA results for pearled FM flour depicts clear indication for peak viscosity, holding time and final point, as these grains do not have any such kind of alteration in their starch pattern.

\section{Conclusion}

Above study confirms the low glycemic index status for foxtail millet owe to its high fibre and low carbohydrate content. Pasting property through RVA for germinated millet flour confirms depletion of starch due to enzyme action, while pearled samples undergo best gelatinization due to availability of same, thus suitable for bakery use as well. Minerals shows reduction in their value after pearling as most of the minerals are confined to bran layers, removed during pearling. Higher phenolic content of germinated rootlets shows their nutraceutical characteristics recognized after high phenolic level. Probably this is the first report based on comparative study for foxtail millet that utilizes megazyme kit for quantitative phytic acid determination from bran, germinated rootlets alongwith raw, germinated and pearled grain flour samples as well. Not only this, the proximate results also scanned and put into the comparison with staple cereals after and before treatment to the test grains. Outcomes were analysed and compiled using statistical means in the form of ANOVA.

\section{References:}

1. Ahmed SMS, Qing Z, Jing C, Qun S (2013) Millet grains: nutritional quality, processing and potential health benefits. Comprehensive reviews in food science and food safety 12: 281-295.

2. Aleksandra M, Saric B, Natasa N, Pestoric M, Milica P et al. (2014) Gluten free cookies enriched with blueberry pomace: Optimization of baking process. International journal of biological veterinary, agricultural and food engineering 8: 330-333.

3. Makharia KG, Verma AK, Amarchand R, Bhatnagar S, Das P, et al. (2011) Prevalence of celiac disease in northern part of India: A community based study. J Gastroenterol Hepatol 26: 894-900.

4. Ramakrishna BS. (2011) Celiac disease: Can we avert the impending epidemic in India? Indian J Med Res 33: 5-8.

5. Hotz C, Gibson RS (2007) Traditional food-processing and preparation practices to enhance the bioavailability of micronutrients in plant-based diets. J Nutr 37: 1097-1100.

6. Pederson HB, Holm PB, Kristiansen KN (2002) Transgenic approaches in commonly consumed cereals to improve iron and zinc content and bioavailability. J Nutr 32: 514-516.

7. Sinha VK, Kumar A, Makkar PS, Harinder, Becker K (2010) Dietary roles of phytate and phytases in human nutrition: A Review. Food Chemistry 120: 945-959.

8. Raboy V (2001) Seeds for a better future: Low phytate grains help to overcome malnutrition and reduce pollution. Trends in Plant Science 6: 458-462.

9. Pradeep SR, Guha M (2011) Effect of processing methods on the nutraceutical and antioxidant properties of little millet extracts. Food Chemistry 126: 1643-1647.

10. Proximate analytical methods (1984) AOAC Official method of analysis 1984.14 of analysis, Washington, DC, USA.

11. Pollman RM (1991) Atomic absorption spectrophotometric determination of calcium and magnesium and phosphorous in cheese: collaborative study. $J$ Assoc Off Anal Chem 74: 27-31.

12. Singelton VL, Orthofer R, Lamuela-Raventos RM (1999) Analysis of tota phenols and other oxidation substrates and antioxidants by means of FolinCiocalteu reagent. Methods in Enzymology 299: 152-178.

13. Velasquez E, Tournier HA, Mordujovichole BP, Saadevra G, Scinella GR (2003) Antioxidant activity of Paraguayan plants extracts. Fitoterapia 74: 91-97.

14. Kemme PA, Jongbloed AW, Mroz Z, Kogut J, Beynen AC (1999a) Digestibility of nutrients in growing finishing pigs is affected by Aspergillus niger phytase, phytate and lactic acid levels: 1. Apparent ileal digestibility of amino acids Livestock Product Science 58: 107-117.

15. Cheryan M (1980) Phytic acid interactions in food systems. CRC Critica Reviews in Food Science and Nutrition 13: 297-335.

16. Greiner R, Konietzny U (1999) Improving enzymatic reduction of myo-inosito phosphates with inhibitory effects on mineral absorption in black beans (Phaseolus vulgaris var Preto). J of Food Processing and Preservation 23: 249-261.

17. Dykes L, Rooney LW (2006) Sorghum and Millet phenols and antioxidants. J of Cereal Science 44: 236-251.

18. Abdoulaye C, Jie C (2011) Evolution of energetic compounds, antioxidant capacity some vitamins and minerals, phytase and amylase activity during the germination of Foxtail millet. American J of Food Technology 6: 40-51.

19. Chandrasekara A, Naczk M, Shahidi F (2012) Effect of processing on the antioxidant activity of millet grains. Food Chemistry 133: 1-9. 